\title{
The Present-day Stress Pattern in the Middle East and Northern Africa and Their Importance: The World Stress Map Database Contains the Lowest Wellbore Information in these Petroliferous Areas
}

Mojtaba Rajabi, Mark Tingay, Australian School of Petroleum, The University of Adelaide, and Oliver Heidbach, GFZ German Research Centre for Geosciences

This paper was selected for presentation by an IPTC Programme Committee following review of information contained in an abstract submitted by the author(s). Contents of the paper, as presented, have not been reviewed by the International Petroleum Technology Conference and are subject to correction by the author(s). The material, as presented, does not necessarily reflect any position of the International Petroleum Technology Conference, its officers, or members. Papers presented at IPTC are subject to publication review by Sponsor Society Committees of IPTC. Electronic reproduction, distribution, or storage of any part of this paper for commercial purposes without the written consent of the International Petroleum Technology Conference is prohibited. Permission to reproduce in print is restricted to an abstract of not more than 300 words; illustrations may not be copied. The abstract must contain conspicuous acknowledgment of where and by whom the paper was presented. Write Librarian, IPTC, P.O. Box 833836, Richardson, TX 75083-3836, U.S.A., fax +1-972-952-9435

\begin{abstract}
Knowledge of the present-day stress field is vital for a range of earth science disciplines, including hydrocarbon and geothermal energy production, mine safety and seismic hazard assessment. The scientific importance of understanding the present-day maximum horizontal stress orientation has been demonstrated by the findings of the World Stress Map (WSM) Project, which has spent over 25 years building an extensive freely-available repository of present-day stress information as a collaborative project between academia, industry and government. The WSM project has revealed that the plate scale presentday stress is controlled by the tectonic forces exerted at tectonic plate boundaries. However, numerous studies in sedimentary basins have shown that stresses in the oil-patch can be complex, and controlled by both major far-field forces (plate boundaries, body forces from mountain belts) and intra-basinal forces, such as detachment zones, salt, faults and basin geometry.

The World Stress Map project contains free and public information for over 80 basins around the world. However, the project contains almost no wellbore data for the Middle East and Northern Africa, despite this region hosting much of the world's global oil production and extensive industry activity. To date, the World Stress Map Project only contains limited datasets from petroleum wells in Egypt, Oman and Iran - but no data at all for Saudi Arabia, Iraq, Libya, Algeria, UAE, Kuwait or Qatar.

In this paper we first review different methods for determining and calculating the present-day stress pattern in the region, then we highlight the lessons learned from the World Stress Map project on the controls of present-day stress in the oil-patch. Finally, we focus in detail on the stress data that currently exists for the Middle East and Northern Africa.
\end{abstract}

\section{Introduction}

Knowledge of the crustal present-day stress pattern is important for a range of earth science disciplines including:

- Geodynamic applications (e.g. Richardson 1992; Zoback 1992);

- Neotectonic and intraplate deformation (e.g. Tingay et al. 2005; King et al. 2010);

- Geomechanical characterization of petroleum basins (Tingay et al. 2005);

- $\quad$ Earthquake hazards (Sandiford et al. 2004), and;

- Rock mechanics and engineering (e.g. Reinecker et al. 2006; Zang et al. 2012).

The Present-day stress has numerous applications in petroleum basins, particularly in borehole stability, reservoir drainage and flooding patterns, pore pressure prediction, fluid flow in naturally-fractured reservoirs, hydraulic fracture stimulation, seal breach by fault reactivation and any geomechanical modeling. Hence, present-day stress analysis, as a part of 'petroleum geomechanics', has received extensive attention in petroleum industry in recent years (Barton et al., 1995; Sibson, 1996; Jones and Hillis, 2003; Rajabi et al., 2010; Tingay et al., 2010a and b).

The World Stress Map (WSM) project has spent more than 25 years collecting maximum horizontal stress orientations (SHmax) from different stress indicators to make a freely available global database in order to investigate causes and consequences of present-day stress pattern in lithosphere (Figure 1). Plate boundary forces have been highlighted as the main controller of stress pattern, particularly for stable North America, Western Europe and South America continental areas, since 
the publication of the first version of WSM project (Richardson, 1992; Zoback 1992). However, there remains numerous questions about the controls and origins of stress perturbations at different scales, from plate scale to small basins.

The 2008 release of WSM project which contains 21750 crustal SHmax orientations from different depths of lithosphere from all over the world revealed the complexity of the global stress pattern (Heidbach et al., 2010). In the WSM database there are several sources of information that each provide SHmax orientation from certain depth of lithosphere. For example, earthquake focal mechanism solutions provide valuable stress data from the deeper parts of the Earth's crust (5 to $40 \mathrm{~km}$ ). Borehole breakouts and induced tensile fractures, commonly observed in wellbores, provide the primary and most reliable stress information in petroleum provinces, whilst engineering methods used in mines and tunnels are suitable in the upper 1 $\mathrm{km}$ of the crust. Finally, geological features, such as fault slips, are the main sources for the present-day stress at the surface (Tingay et al. 2005).

The WSM project contains free and public information for over 80 basins around the world. However, the project contains almost no wellbore data for the Middle East and Northern Africa (Heidbach et al., 2009). Knowledge of present-day stress is a vital importance for these petroliferous areas, not only for petroleum applications but also in stress-related geohazards. To date, the database only contains limited datasets from petroleum wells in Egypt, Oman and Iran (Tingay et al., 2011 and 2012; Rajabi 2009; Rajabi et al., 2010; Yaghoubi and Zeinali, 2009; Haghi et al., 2013) - but no reliable data at all for Saudi Arabia, Iraq, Libya, Algeria, UAE, Kuwait or Qatar, which considered one of the most petroliferous regions in the world.

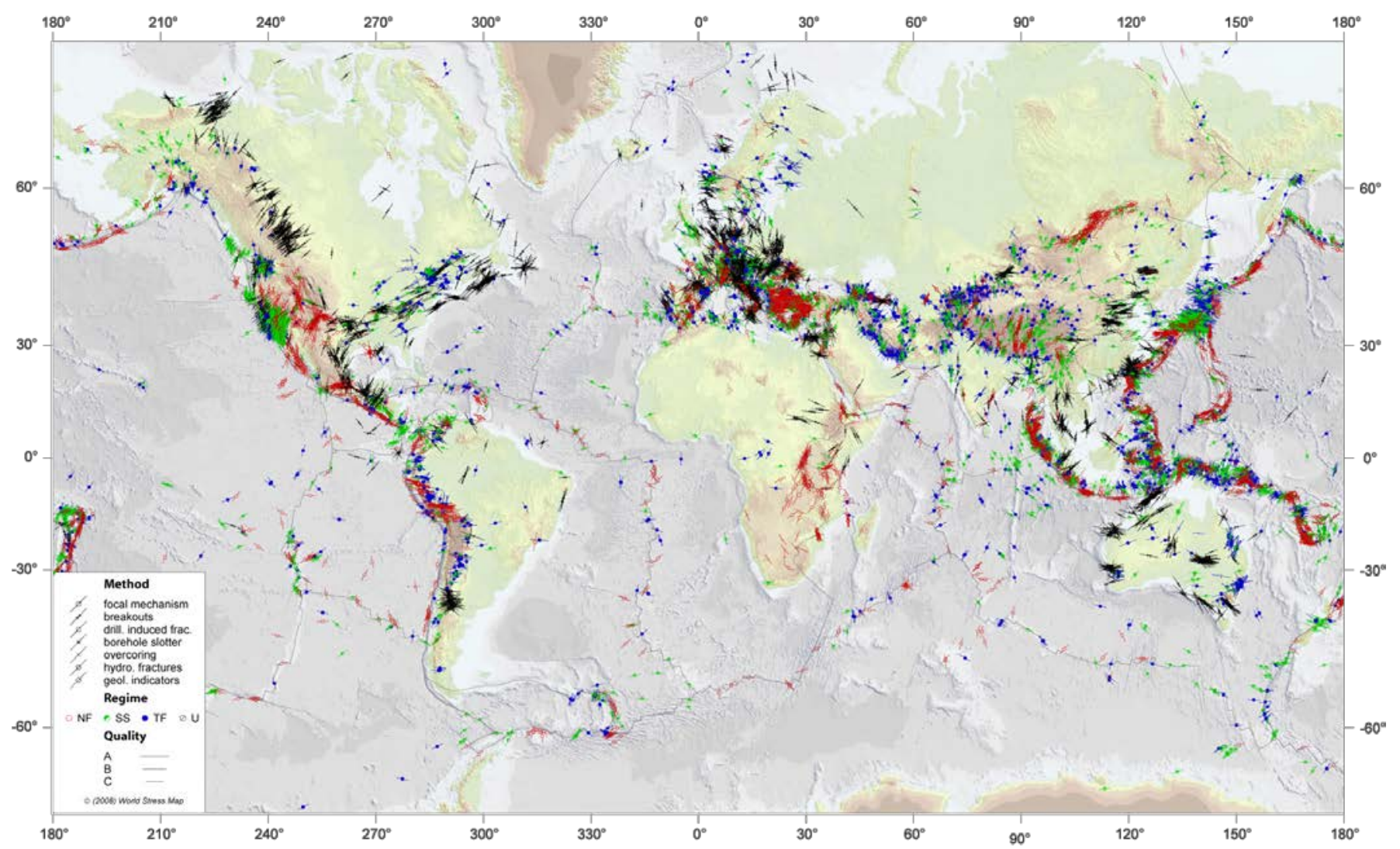

Figure 1: Global stress map based on the WSM database release 2008 using the 11346 stress data records from a variety of stress measurement techniques with A-C quality (Heidbach et al., 2009). Symbols and different colours indicate the method of measurement and the stress regime $(\mathrm{NF}=$ normal faulting stress regime; $\mathrm{SS}=$ strike-slip faulting stress regime; $\mathrm{TF}=$ thrust faulting stress regime; black=undefined stress regime). Length of the lines indicates quality of data. All data and maps are freely available on the WSM website: www.world-stress-map.org.

\section{Methods to determine the orientation of maximum horizontal stress in petroleum wells}

The state of stress is commonly described by stress tensor. In sedimentary basins, one of the principal stresses is considered vertical because the Earth's surface cannot transmit shear stresses (Bell, 1996). Hence, the stress tensor can be simplified to four components, the magnitudes of the vertical, maximum and minimum horizontal stresses in addition to the orientation of the maximum horizontal stress (Bell, 1996; Tingay et al., 2009). Of these four components, the maximum horizontal stress orientation has received extensive attention, particularly in geodynamic and plate motion (e.g. Richardson 1992; Zoback 1992), neotectonic studies (e.g. Zhang et al. 1996; Tingay et al. 2005; King et al. 2010), fluid flow in fractured reservoirs (e.g. Barton et al. 1995, Sibson, 1996; Finkbeiner et al., 1997; Major and Holtz 1997; Laubach et al., 2004) and fault reactivation (e.g. Jones and Hillis, 2003). Hence, the WSM project has mainly focused on this informative parameter and compiled a public global database to determine and understand the state of present-day stress in the Earth's lithosphere. It should be noted that there are no 'direct' methods to measure crustal present-day stresses and all techniques indirectly relate observed strains in the 
Earth to the stresses that most likely cause those strains. In this paper, we focus on stress orientations determined from petroleum wells, in particular borehole breakouts and drilling-induced fractures.

When a borehole is drilled, the material removed from the subsurface is no longer supporting the surrounding rock (the wellbore wall). As a result, the stresses become concentrated in the wellbore wall (Kirsch, 1898). Borehole breakouts (BOs) are stress-induced elongations of the wellbore and occur when the wellbore stress concentration (circumferential or hoop stress) exceeds that required to cause compressive failure of intact rock (Bell and Gough, 1979). The elongation of the crosssectional shape of the wellbore is the result of compressive shear failure on intersecting conjugate planes, which causes pieces of the borehole wall to spall off (Bell and Gough, 1979). The maximum circumferential stress around a vertical borehole occurs perpendicular to SHmax (Kirsch, 1898). Hence, borehole breakouts are elongated perpendicular to the present-day SHmax direction (Bell and Gough, 1979). Drilling-induced tensile fractures (DITFs) are caused by tensile failure of the borehole wall and form when the wellbore stress concentration is less than the tensile strength of the rock. Hence, DITFs form parallel to the SHmax orientation in vertical boreholes.

\section{Determination of SHmax orientation from caliper tools}

Caliper tools are routinely run in petroleum wells in order to obtain dip and strike of drilled formations and measure borehole geometry to calculate the required cement volume for the casing. Four-arm and six-arm are two common types of caliper tools that are run in petroleum wells. Four-arm caliper tool measure well diameter in two orthogonal directions. Hence, several features including keyseat, washout and breakout can be interpreted via these logs (Figure 2; Reinecker et al. 2003). However, determination of borehole enlargements in 6-arm caliper is more complicated than 4-arm tool (Figure 2) because six-arm caliper tool has two extra arms with angular distances of $60^{\circ}$ and independent hinges of the arms may cause a tool decentralization that should be corrected (Wagner et al., 2004).
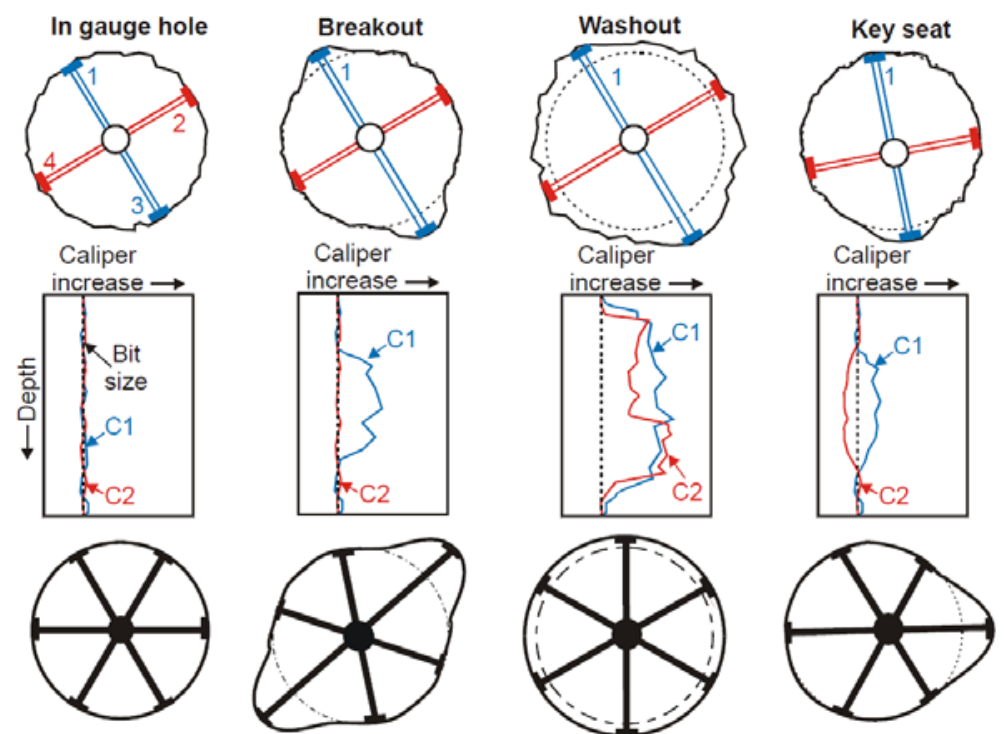

Figure 2: Different types of borehole enlargements in four- and six-arm caliper tools. First and second rows are borehole elongations and response of 4 arm caliper (after Plumb and Hickman, 1985 from Reinecker et al. 2003). Borehole breakouts are those type enlargements that one caliper is reading larger than bit size. Third row is borehole wall features in 6-arm caliper tool (Wagner, 2003). All caliper readings are (roughly) on and larger than bit size in an in-gauge hole and washout zone respectively (note than in these two enlargements, tools are (or nearly) centralized). In most cases, key seats in 6-arm caliper tool in not centralized, while in borehole breakout zone the tools can be or not centralized due to shape of breakouts.

\section{Determination of SHmax orientation from borehole image tools}

Borehole image tools are currently available as wireline and logging/measurement while drilling (LWD/MDW) tools and provide an image from the borehole wall based on physical property contrasts (Prensky, 1999; Tingay et al., 2008). Nowadays several types of borehole image tools with different names are running in petroleum industry. Prensky (1999) categorized the borehole image tools to three main groups (i.e. optical, acoustic and electrical), but density image tools are being new LWD/MWD tool in petroleum industry and can be used in borehole breakout interpretation.

Borehole breakouts and drilling induced tensile fractures can be interpreted in different types of image logs. For example, in acoustic images borehole breakouts appear (primarily the travel time image) as a pair of wellbore elongation zones parallel to the borehole axis and separated by approximately $180^{\circ}$, while breakouts appear as broad, parallel, often poorly resolved conductive zones separated by $180^{\circ}$ and exhibiting caliper enlargement in the direction of the conductive zones (Bell, 1996; Tingay et al., 2008) in resistivity (electrical) images (Figure 3). Drilling induced tensile fractures appear as pairs of narrow conductive features (on resistivity images) or low-amplitude features (on acoustic images) that are generally parallel to the borehole axis and separated by approximately $180^{\circ}$ (Figure 3; Tingay et al., 2005). 
All stress indicators in the WSM database are quality-ranked from A-quality (highest; stress orientation accurate to within \pm 150 ) to E-quality (lowest; no reliable stress orientation). The WSM quality ranking criteria for BOs in Caliper and image logs and DITFs in image logs can be found freely as guidelines on the WSM website.

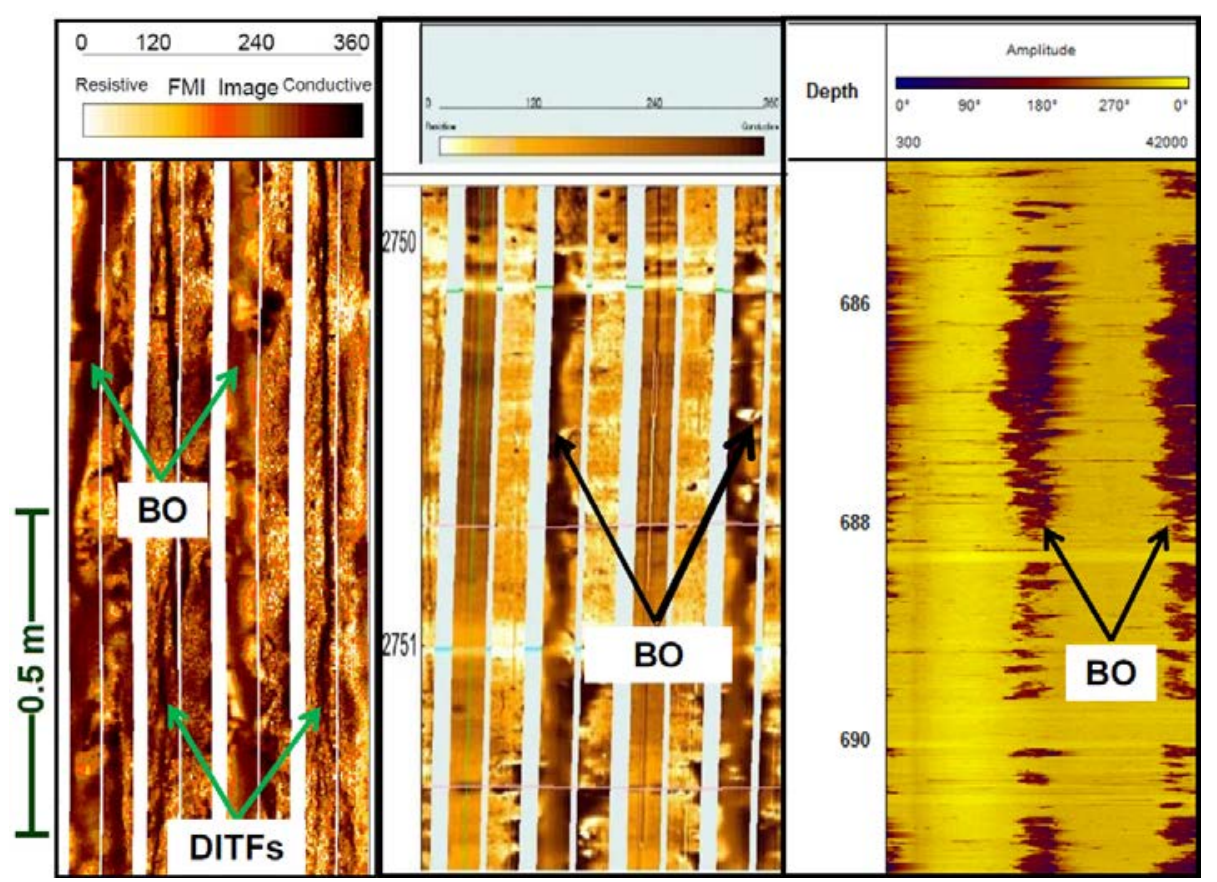

Figure 3: Example of borehole breakout (BO) and drilling-induced tensile fractures (DIFs) interpreted in image logs. Left) BOs and DITFs in resistivity image (FMI) pictured herein are oriented approximately N-S and E-W respectively, and thus indicates a present-day SHmax orientation of

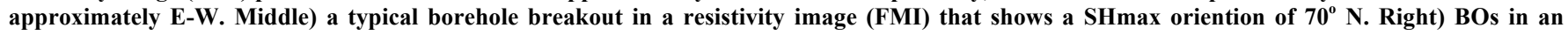
acoustic image (AST) that approximately are oriented N-S (SHmax $\approx \mathrm{E}-\mathrm{W})$.

\section{The World Stress Map project: history, results and lessons}

The World Stress Map (WSM) project started in 1986 as a project of "International Lithosphere Program" and under the leadership of Mary Lou Zoback to determine the state of crustal present-day stress. The first public access of this project was released with 3574 in-situ stress data records in 1989 and then first published in 1992 containing 7300 data records (Zoback et al., 1989 and 1992). The WSM was a project of the "Heidelberg Academy of Sciences and Humanities" at the University of Karlsruhe from 1995 to 2008 . The 2005 version of the WSM contained more than 14000 data records. Since 2008 the WSM has been a part of "GFZ German Research Centre for Geosciences". The latest version of WSM (released in 2008) contains 21750 maximum horizontal stress orientations interpreted from a range of contemporary stress indicators within the upper 40 $\mathrm{km}$ of the Earth's lithosphere (Heidbach et al. 2010). It should be noted that all the results of WSM project are freely available on the World Stress Map website (www.world-stress-map.org) for public use.

The initial version of WSM (Zoback, 1992) and further studies by Richardson (1992) revealed that the SHmax orientation in most tectonic plates is approximately parallel to absolute plate motion, suggesting that the plate boundary forces that drive plate motion also control the intra-plate stress field. Although the state of stress in large scale (i.e. plate) is relatively understood, the state and origin of stress in smaller scale (such as sedimentary basins or even petroleum fields and reservoirs) remain poorly understood in comparison (Bell, 1996; Tingay et al., 2005; Tingay et al., 2006). Hence, the WSM project undertook the 'present-day stress in sedimentary basins initiative' from 2004-2006, to investigate the state and origin of present-day stress in smaller scale (Tingay et al., 2005 and 2006) and mainly based on petroleum or wellbore methods.

Hitherto, detailed analyses in several sedimentary basins revealed that the state of stress in smaller scales can be very simple and consistent over large scale and suggest the present-day stress in these areas directly linked to far field forces (such as Alberta Basin in western Canada (Bell, 1996)); or can be locally varied and highly complex as a result of interaction of different factors acting at different scale (such as North German Basin (Roth and Fleckenstein, 2001); Baram Delta province of Brunei (Tingay et al., 2005 and 2009); Pattani Basin in the Gulf of Thailand; Permian Basin in Texas and New Mexico). These examples, and other studies (in the next section), revealed that the stress state in sedimentary basins is often influenced by a range of factors, and not simply plate boundary forces or major intra-plate stress sources. These factors that mainly are related to geology can act at different scales, including plate boundary forces (e.g. ridge push and slab pull), basin geometry (e.g. shape of deltaic wedge), geological structures (e.g. diapirs, fault and fractures), mechanical contrasts (e.g. evaporites, overpressured shales and detachment zones), topography and deglaciation (Tingay et al., 2006).

For example, detailed studies in Baram Delta System, NW Borneo highlighted the importance of wide tectonic as superposition of forces and explained two different stress provinces in shelfal regions of Brunei where the SHmax orientations 
are margin-normal and margin-parallel in the inner and outer shelf respectively (Tingay et al., 2009; King et al., 2010). Or in another study, stress perturbation on the delta top in Gulf of Mexico have been explained by King et al., (2012) with the presence of salt diapirs and by the means of a Ply3D model.

\section{Present-day stress in the Middle East and North Africa}

The Middle East and Northern Africa contain vast numbers of petroleum wells, but the state of present-day stress in this area's basins is still poorly understood. Indeed, the 2008 World Stress Map database contains very little present-day stress information for this area and almost no stress data from petroleum wells (Figure 4; Heidbach et al., 2009). Indeed, almost all of the stress data currently available for this region is derived from earthquake focal mechanism solutions from events that are typically at depths of ten kilometres or more, and which might not be relevant for petroleum and mining geomechanics applications, particularly in areas possibly detached by salt or low-angle faults. Furthermore, the majority of these earthquake focal mechanism solutions are located along plate boundary, and there are concerns surrounding the reliability of stress information derived from earthquakes near plate boundaries (Heidbach et al., 2010). For example, stress orientations derived from earthquake focal mechanism solutions along the San Andreas Fault Zone and Great Sumatran Fault are often highly inconsistent with those obtained from more reliable petroleum industry data (Zoback et al., 1987; Mount and Suppe, 1992; Heidbach et al., 2010).

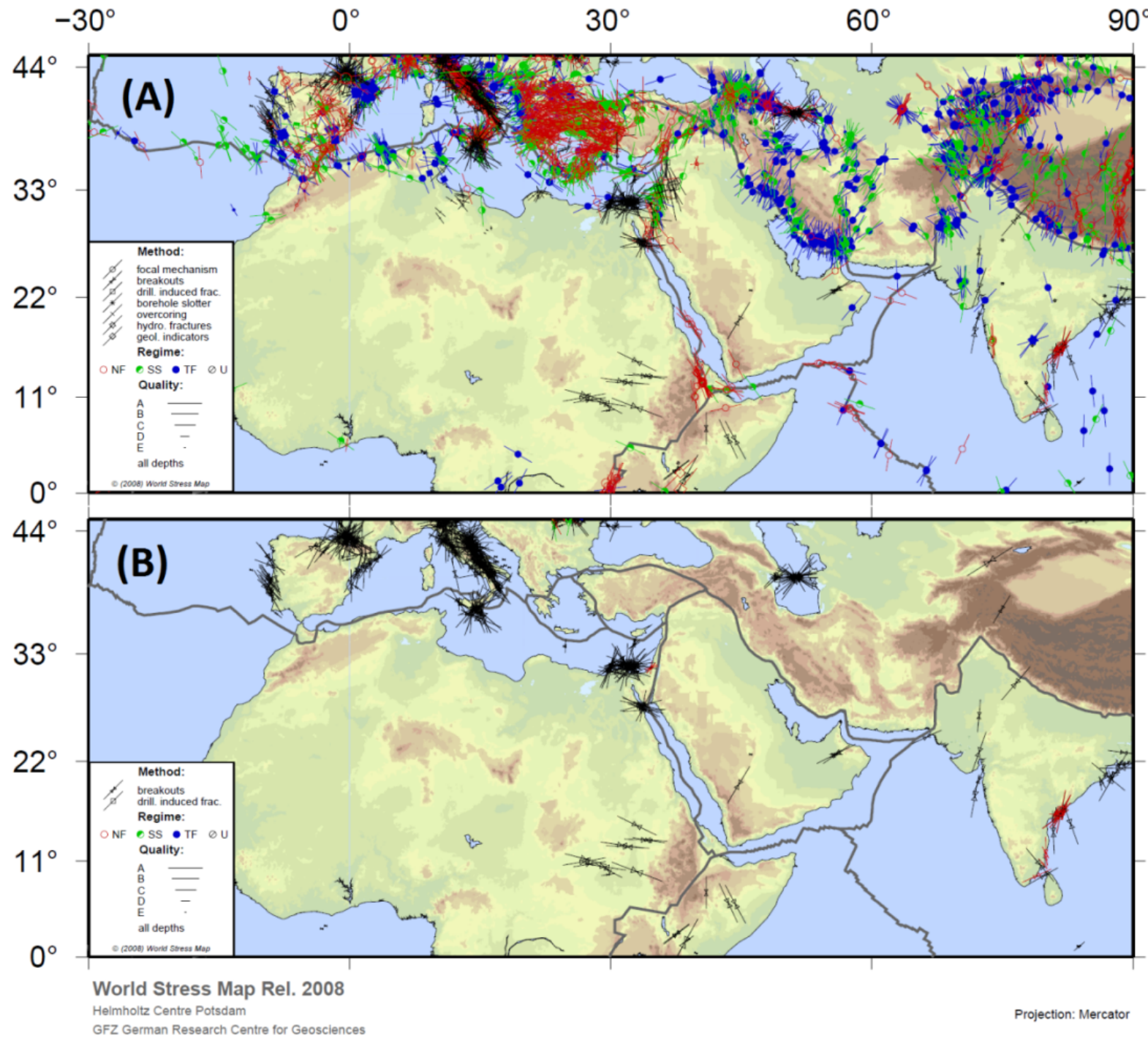

Figure 4: The present-day state of stress (SHmax and stress regimes) in Middle East and Northern Africa derived from all present-day stress indicators in the WSM project (Heidbach et al., 2008). B) Distribution of stress indicators from petroleum industry logging data (caliper tools and borehole imaging data). As can be seen, almost all stress data in this area derived from focal mechanism solutions that give contemporary state of stress in deep lithosphere. Hence, the state of present-day stress is largely unknown in this area. For example, the WSM database contains only three reliable present-day stress indicator from wellbore logging data in the entire Arabian Peninsula (it should be noted that some new results have been recently published from Iran and Egypt and will be included in the new version of WSM). 
To date, the WSM Project only contains limited datasets from petroleum wells in Egypt, Oman and Iran - but no reliable data for Saudi Arabia, Iraq, Libya, Algeria, UAE, Kuwait or Qatar (Figure 4). It should be noted that borehole breakouts and drilling induced tensile fractures of the Khuff Formation, onshore Saudi Arabia, in 19 mjor trap interpreted by Ameen et al., (2010) and suggested two major patterns of SHmax (including E-W to ENE-WSW and NNW-SSE) with some local rotations. However these results were not ranked based on WSM criteria. Herein we provide a brief discussion of the recent studies in these areas:

\section{Offshore Nile Delta}

The Nile delta is the largest clastic sedimentation in the Mediterranean Sea and is comprised of two prograding clastic systems (i.e. Jurassic-Miocene and Pliocene-Recent) that are separated by the major Messinian erosional event and evaporites (Tingay et al., 2012 from, Sestini 1989; Marten et al., 2004). The Nile Delta is located near to several plate boundaries that may influence the orientation of SHmax (Figure 5; Tingay et al., 2012).

A detail analysis of 558 breakouts and 68 drilling induced tensile fractures in 50 wells by Tingay et al., 2011 and 2012 , revealed a significant variation in the orientation of SHmax in sequences above and sequences below or absent of Mesinian evaporites (Figure 5). The present-day SHmax orientations in sequences below or absent of evaporites revealed a well-known example of margin-parallel SHmax orientation of Cenozoic deltas such as Mississippi and Baram Deltas (Yassir and Zerwer, 1997; Tingay et al., 2005; King et al., 2009) that is thought to be generated by the shape of clastic wedge (Figure 6). However, the present-day stress SHmax orientation in sequences above evaporites is highly complicated (even in individual wells) and show a new type of 'non-Andersonian faults' that are oriented at an anomalous angle with respect to intermediate and minimum principal stresses in this extensional system (SHmax and Shmin respectively).

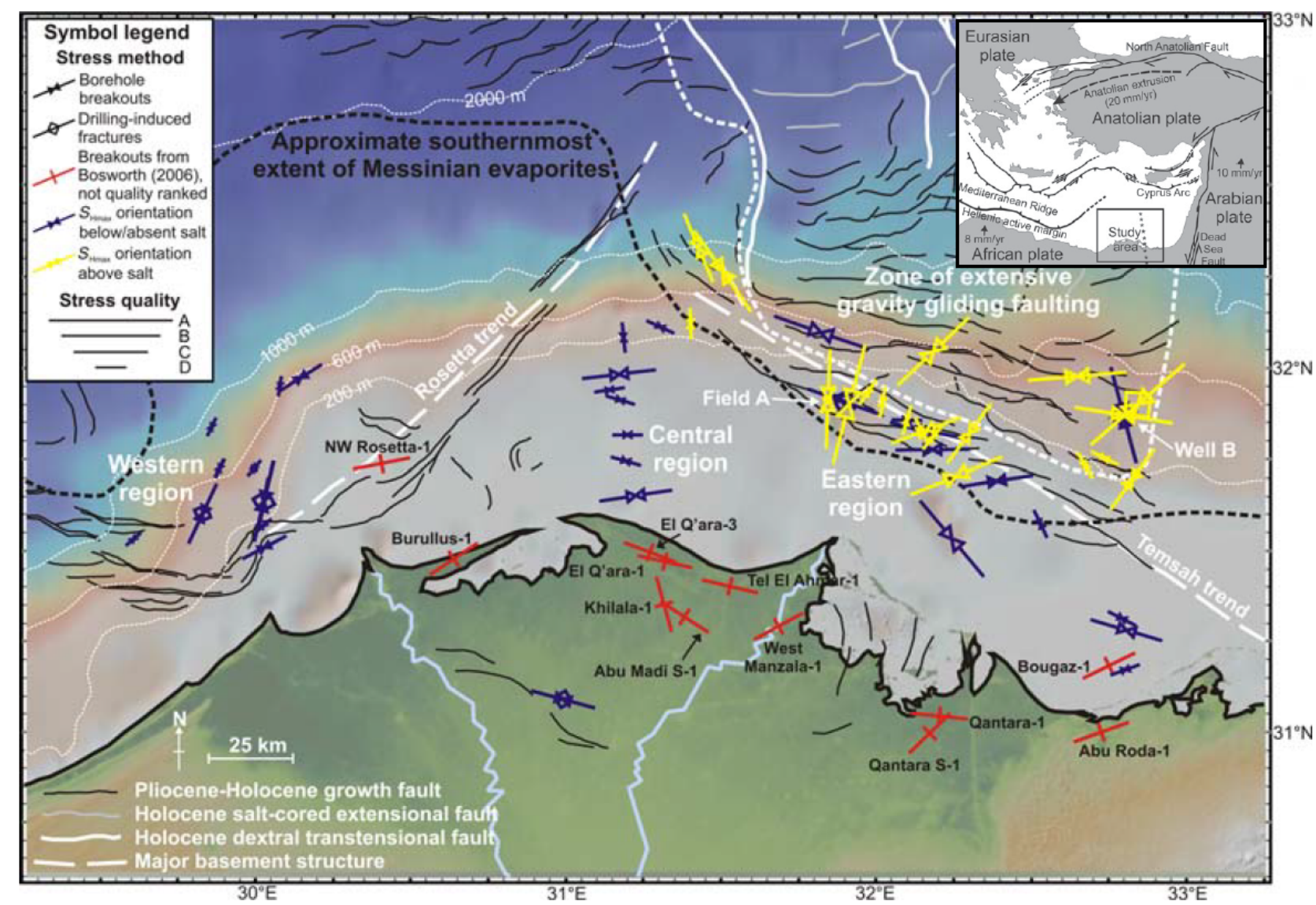

Figure 5: The present-day stress SHmax orientations in Nile Delta (From Tingay et al., 2011 and 2012). SHmax orientation bellow or south of evaporites (blue symbols (Tingay et al., 2012) and red crosses (Bosworth, 2006)) show an approximately NNE-SSW in the western Nile Delta which is a text-book example of margin-parallel deltaic stress field. However, the SHmax orientation is highly scattered for the sequences upper the evaporites. Of course the average SHmax orientation is perpendicular to the margin which is an evidence of a new type of non-Andersonian faulting. 


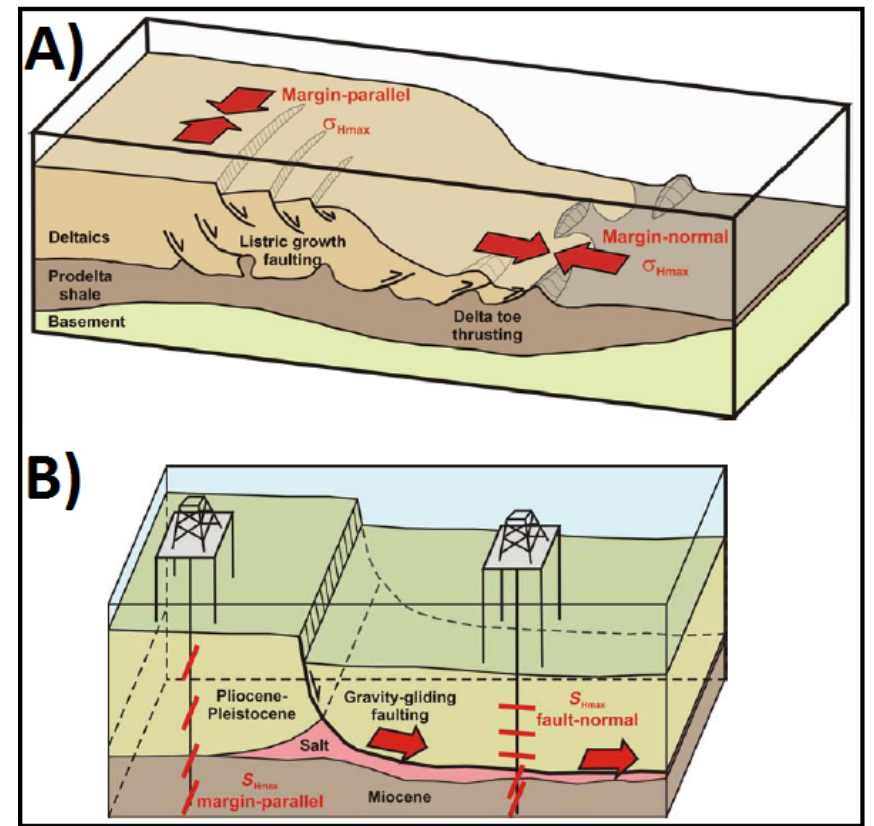

Figure 6: A) a schematic relationship between SHmax orientation and passive-margin Cenozoic deltas' structures (Tingay et al., 2005 adapted from Yassir and Zerwer, 1997). The convex upward shape of the clastic wedge produce a gravity-driven extension toward the delta toe, resulting in margin-parallel SHmax orientation on the shelf and margin-normal thrusting in the delta toe. B) Model proposed by Tingay et al., 2012 for the 'on the shelf' of Nile Delta that shows a margin-parallel for sequences below or absent of evaporites (that are consistent with general models (i.e. A)). However, in sequences above evaporites is the SHmax orientation is in contrary with the general model and is perpendicular to the margin. Tingay et al., 2012 proposed the margin-normal SHmax orientation is result of forces exerted by salt withdrawal.

\section{South and Southwest of Iran}

South and Southwest of Iran is a part of the Zagros fold-and-thrust belt which is a collisional belt between the Iranian block (belonging to Eurasia) and the Arabian plate (McQuarrie, 2004; Alavi, 1994). This area is highly active in terms of plate tectonics and seismicity. Along the plate boundary, there are several SHmax orientation data in the WSM, but all the data are from focal mechanism solutions of earthquake that maybe cannot reveal the state of stress in smaller area (Figure 4). However recent studies in South and Southwest of Iran by Rajabi 2009; Yaghoubi and Zeinali, 2009; Rajabi et al., 2010 and Haghi et al., 2013 revealed a correlation between SHmax orientations derived from breakouts and earthquake focal mechanism solutions in near plate boundaries and suggesting that focal mechanism solution data near continental collision zones may provide reliable information of the stress orientation. However, Yaghoubi and Zeinali, 2009 in one of the studied wells in SW Iran found a standard deviation of $26^{\circ}$ for SHmax orientation determined from image log. In addition, some new unpublished wellbore results far away the plate boundary show some perturbation in SHmax orientation, which is reasonable due to presence of several detachment zones (such as evaporites and shales), active fault and fracturing in this area.

\section{Summary and Conclusions}

The WSM project has complied (over more than 25 years) a public global data set of the present-day tectonic stress information to determine and understand the state of stress in the Earth's lithosphere. The crustal present-day stresses in most tectonic plates are controlled by plate boundaries (such as ridge push and slab pull) or by large intraplate features. However, the state of stress in small scale is highly complex and is still under exploration. Yet, the WSM project contains free and public information for over 80 basins around the world, but except a detail study in Nile Delta and some other petroleum wells in Iran and Oman there is not any wellbore information in the Middle East and Northern Africa which contain a numerous petroleum wells.

In addition, results of the WSM project (particularly since the 'Present-day stress in sedimentary basins initiative' in WSM project in 2004) have revealed that the contemporary state of stress can be influenced by several factors (geological features and contrasts) and a single strategy cannot be adopted to predict present-day stress in different sedimentary basins. Even, recent studies in Nile Delta revealed several issues that are in contrary with previous hypotheses.

Although the Most comprehensive application of the present-day stress orientation are in petroleum industry (for borehole stability, reservoir drainage, pore pressure prediction, fluid flow in naturally-fractured reservoirs, hydraulic fracture stimulation and seal breach by fault reactivation) but it has a lot of applications in geodynamics, neotectonics, earthquake hazard and rock mechanics/engineering. Hence, knowledge of the present-day stress orientation is particularly important in this area which this area has an extensive and mature petroleum exploration and production industry; and also is located in an active earthquake belt that is prone to stress related geohazards such as earthquakes. 


\section{References}

Alavi, M., 1994. Tectonics of the Zagros orogenic belt of Iran: new data and interpretations. Tectonophysics 229, 211-238.

Ameen, M.S., Buhidma, I.M., Rahim, Z., 2010. The function of fractures and in-situ stresses in the Khuff reservoir performance, onshore fields, Saudi Arabia. AAPG Bulletin 94, 27-60.

Barton, C.A., Zoback, M.D., Moos, D., 1995. Fluid flow along potentially active faults in crystalline rock. Geology 23 (8), $683-686$.

Bell, J. S. 1996. Petro Geoscience 2. In situ stresses in sedimentary rocks (Part 2): Applications of stress measurments. Geoscience Canada $23,135-153$

Bell, J.S., Gough, D.I., 1979. Northeast-southwest compressive stress in Alberta: evidence from oil wells. Earth and Planetary Science Letters 45, 475-482.

Finkbeiner, T., Barton, C.A., Zoback, M.D., 1997. Relationships among in-situ stress, fractures and faults, and fluid flow: Monterey Formation, Santa Maria Basin, California. . AAPG Bulletin 81 (12), 1975-1999.

Haghi, A.H., Kharrat, R., Asef, M.R., . Rezazadegan, H. 2013. Present-day stress of the central Persian Gulf: Implications for drilling and well performance, Tectonophysics, http://dx.doi.org/10.1016/j.tecto.2013.06.001.

Heidbach, O., Tingay, M.R.P., Barth, A., Reinecker, J., Kurfeß, D., Müller, B., 2009. The World Stress Map based on the database release 2008, 1. Commission of the Geological Map of the World, Paris, p. 46. doi:10.1594/GFZ.WSM.Map2009. M.

Heidbach, O., Tingay, M.R.P., Barth, A., Reinecker, J., Kurfe $\beta$, D., Müller, B., 2010. Global crustal stress pattern based on the World Stress Map database release 2008. Tectonophysics 482, 3-15.

Jones, R.M., Hillis, R.R., 2003. An integrated, quantitative approach to assessing fault-seal risk. AAPG Bulletin 347, $189-215$.

King, R.C., Backé, G., Tingay, M.R.P., Hillis, R.R., Mildren, S., 2012. Stress deflections around salt diapirs in the Gulf of Mexico. In: Healy, D., Butler, R. W. H., Shipton, Z. K. \& Sibson, R. H. (eds) 2012. Faulting, Fracturing and Igneous Intrusion in the Earth's Crust. Geological Society, London, Special Publications, 367, 141-153.

King, R. C. Hillis, R. Tingay, M. and Damit, A. R. 2010. Present-day stresses in Brunei, NW Borneo: superposition of deltaic and active margin tectonics. Basin Research 22, 236-247.

Kirsch, V., 1898. Die Theorie der Elastizität und die Bedürfnisse der Festigkeitslehre. Zeitschrift des Vereines Deutscher Ingenieure 29, 797-807.

Laubach, S.E., Olson, J.E., Gale, J.F.W., 2004. Are open fractures necessarily aligned with maximum horizontal stress? Earth and Planetary Science Letters 222, 191-195.

Major, R.P., Holtz, M.K., 1997. Identifying fracture orientation in Mature Carbonate Platform reservoir. AAPG Bulletin 81 (7), $1063-1069$.

Marten, R., Shann, M., Mika, J., Rothe, S, Quist, Y. 2004. Seismic challenges of developing the pre-Pliocene Akhen field offshore Nile Delta. The Leading Edge 23, 314-320.

McQuarrie, N., 2004. Crustal scale geometry of the Zagros fold-thrust belt. Iran. Journal of Structural Geology 26 519-535.

Mount, V.S., Suppe, J., 1992. Present-day stress orientations adjacent to active strike-slip faults: California and Sumatra. Journal of Geophysical Research 97 11995-12013.

Prensky, S., E., 1999. Advances in borehole imaging technology and applications. In: Lovell, M. A., Williamson, G. and Harvey, P. K. (Eds) 1999. Borehole Imaging: applications and case histories. Geological Society, London, Special Publications 159, 1-43.

Rajabi, M. 2009. Fracture analysis and petrophysical evaluation using well log data in one of the Iranian Southwestern oil reservoirs, Unpublished M.Sc. Thesis, University of Tehran.

Rajabi, M., Sherkati, S., Bohloli, B., Tingay, M. 2010. Subsurface fracture analysis and determination of in-situ stress direction using FMI logs: An example from the Santonian carbonates (Ilam Formation) in the Abadan Plain, Iran, Tectonophysics 492, 192-200.

Reinecker, J. Tingay, M. and Müller, B. 2003. Borehole breakout analysis from four-arm caliper logs. World Stress Map Project Guidelines (available online on world-stress-map.org).

Reinecker, J. Tingay, M. and Müller, B. 2006. The use of the World Stress Map database for rock engineers. In: M. Lu, C. Li, H. Kjørholt, H. Dahle, (eds.), In-situ Rock Stress Measurement, Interpretation and Application. Taylor and Francis Group, 505-510, London.

Richardson, R.M., 1992. Ridge forces, absolute plate motions, and the intraplate stress field. Journal of Geophysical Research 97, 1173911748.

Roth F. and P. Fleckenstein. 2001. Stress orientations found in north-east Germany differ from the West European trend. Terra Nova 13, 289-296.

Sandiford, M. Wallace, M. and Coblentz, D. 2004. Origin of the in situ stress field in southeastern Australia. Basin Research 16, 325-338.

Sestini, G. 1989. Nile Delta: a review of depositional environments and geological history. In: Whateley, M. K. G. and Pickering, K. T. (eds) Deltas: Sites and Traps for Fossil Fuels. Geological Society, London, Special Publications 41, 99-127.

Sibson, R.H., 1996. Structural permeability of fluid-driven fault-fracture meshes. Journal of Structural Geology 18, $1031-1042$.

Tingay, M., Bentham, P., De Feyter, A. and Kellner, A., 2011. Present-day stress field rotations associated with evaporites in the offshore Nile Delta. Geological Society of America Bulletin 123, 1171-1180.

Tingay, M., Bentham, P., De Feyter, A. and Kellner, A., 2012. Evidence for non-Andersonian faulting above evaporites in the Nile Delta. In: Healy, D., Butler, R. W. H., Shipton, Z. K. \& Sibson, R. H. (eds) 2012. Faulting, Fracturing and Igneous Intrusion in the Earth's Crust. Geological Society, London, Special Publications 367, 155-170

Tingay, M., Hillis, R., Morley, C., King, R., Swarbrick, R., Damit, A. 2009. Present-day stress and neotectonics of Brunei: implications for petroleum exploration and production. American Association of Petroleum Geologists Bulletin 93, 75-100.

Tingay, M. Morley, C., Hillis, R., Meyer, J., 2010a. Present-day stress orientation in Thailand's basins. Journal of Structural Geology 32, $235-248$.

Tingay, M. Morley, C., King, R., Hillis, R., Hall, R., Coblentz, D., 2010b. The Southeast Asian Stress Map. Tectonophysics $482,92-104$.

Tingay, M. Müller, B., Reinecker, J. and Heidbach, O., 2006. State and Origin of the Present-Day Stress Field in Sedimentary Basins. In: American Rock Mechanics Association/ 41st U.S. Symposium on Rock Mechanics. 06-1049.

Tingay, M. Muller, B. Reinecker, J. Heidbach, O. Wenzel, F. Flecknstein P. 2005. Understanding tectonic stress in the oil patch: the World Stress Map Project The Leading Edge 24 (12), 1276-1282. 
Tingay, M., Reinecker, J., Müller, B., 2008. Borehole breakout and drilling-induced fracture analysis from image logs. World Stress Map Project Stress Analysis Guidelines. available online on the WSM website: www.world-stress-map.org.

Wagner, D., 2003. Contemporary tectonic stress derived from oriented 6-arm caliper logs. Unpublished Diploma thesis. University of Karlsruhe.

Wagner, D., Müller, B. and Tingay, M.R.P., 2004. Correcting for tool decentralization of oriented six-arm caliper logs for determination of contemporary tectonic stress orientation. Petrophysics 45, 530-539.

Yaghoubi, A.A., Zeinali, M., 2009. Determination of magnitude and orientation of the in-situ stress from borehole breakout and effect of pore pressure on borehole stability — case study in Cheshmeh Kush oil field of Iran. Journal of Petroleum Science and Engineering 67, $116-126$.

Yassir, N. A., Zerwer, A. 1997. Stress regimes in the Gulf Coast, offshore Louisiana: data from well-bore breakout analysis. American Association of Petroleum Geologists Bulletin 81, 293-307.

Zang, A. Stephansson, O. Heidbach, O. and Janouschkowetz, S. 2012. World Stress Map Database as a Resource for Rock Mechanics and Rock Engineering. Geotechnical and Geological Engineering 30, 625-646.

Zhang, Y. Scheibner, E. Ord, A. and Hobbs, B. E. 1996. Numerical Modelling of Crustal Stresses in The Eastern Australian Passive Margin. Australian Journal of Earth Sciences 43, 161-175.

Zoback, M.L. 1992. First- and second-order patterns of stress in the lithosphere: the world stress map project. Journal of Geophysical Research 97 (B8): 11703-11728.

Zoback, M. L. Zoback, M. D. Adams, J. Assumpcao, M. Bell, S. Bergman, E. A. Blumling, P. Bereton, N. R. Denham, D. Ding, J. Fuchs, K. Gay, N. Gregersen, S. Gupta, H. K. Gvishiani, A. Jacob, K. Klein, R. Knoll, P. Magee, M. Mercier, J. L. Muller, B. C. Paquin, C. Rajendran, K. Stephansson, O. Suarez, G. Suter, M. Udias, A. Xu, Z. H. and Zhizhin, M. 1989. Global patterns of tectonic stress, Nature 341, 291-298.

Zoback, M.D., Zoback, M.L., Moun, V.S., Suppe, J., Eaton, J.P., Healy, J.H., Oppenheimer, D., Reasenberg, P., Jones, L., Raleigh, C.B., Wong, I.G., Scotti, O., Wentworth, C., 1987. New evidence on the state of stress of the San Andreas Fault system. Science 238, 11051111. 